\title{
Biyi Bandele's Theatre of the Afropolitan Absurd
}

\author{
Michael Pearce
}

Biyi Bandele (also referred to as Biyi Bandele-Thomas) is a novelist, poet, filmmaker and playwright. He was born in 1967 into a middle-class Yoruba family and grew up in the multi-ethnic and multi-religious town of Kafanchan, located in the north of Nigeria. Bandele immigrated to England after his one-act play Rain won the $13^{\text {th }}$ International Student Playscript competition in 1989. ${ }^{1}$ Since his relocation, Bandele has had a number of plays produced by prominent British theatres, including the Royal Court and the Royal Shakespeare Company, marking him as one of the UK's most successful African British dramatists. ${ }^{2}$ Despite this, it is his novels not his plays that have received the most academic attention. ${ }^{3}$ This can be attributed to Bandele's immigrant status (most of his plays have been staged in the UK not Nigeria) and his preoccupation with Africa in his plays (first-generation immigrant dramatists who explore life in the UK tend to be better represented, for instance Trinidadian Mustapha Matura). ${ }^{4}$ This chapter initiates an overdue discussion of Bandele's early plays Marching for Fausa (1993, Royal Court), Two Horsemen (1994, The Gate) and Resurrections in the Season of the Longest Drought (1994, Cochrane). It examines theses plays through two distinct but related lenses. For classification purposes, the plays are situated within the tradition of the African Absurd. They are then analysed through the transnational concept of Afropolitanism. Although the plays predate the term Afropolitan, this chapter demonstrates how the concept's articulation of globalized African identities and cultures provides an ideal framework through which to comprehend the complex conditions of their production and the political and cultural issues with which they engage. Detailed discussions of both concepts will now follow.

\section{Theatre of the African Absurd}

As its name suggests, Theatre of the African Absurd describes the meeting of African and European dramatic modes and the creation of new, hybrid forms. Its lines of influence can be traced back to post-war European literary as well as African oral traditions (Balogun 1984, 43-44). Martin Esslin coined the term 'Theatre of the Absurd' in 1962 to describe a new dramatic style that emerged in European plays in 
the wake of the cataclysm of the Second World War. Although existentialist dramas were not novel, what was remarkable about these plays, according to Esslin, was that their thematic exploration of the senselessness of the human condition was accompanied by a stylistic 'open abandonment of rational devices and discursive thought' (Esslin 2014, 5). In the 1980s and 1990s the label African Absurd came to be attached to a number of novelists, poets and playwrights whose work also emerged in response to crisis, in this instance the political unrest, social upheaval and economic collapse experienced by many African countries following decolonisation (Balogun 1984; Kesteloot 1996). According to Lilyan Kesteloot in her essay Turning Point in the Francophone/African Novel: The Eighties to the Nineties, the writing style of this new school often, although not always, complemented their thematic exploration of existential angst: 'according to their inspiration and ability, in realistic mode, but more often hallucinatory even delirious, they vent forth through their writing a reality that borders on nightmare $(1996,6)$. In terms of Bandele's experiences growing up in Nigeria, he was born at the start of the bloody Biafra Civil War (1967-1970) that followed Nigerian independence in 1960. And, although the country witnessed economic growth during his childhood years, over dependence on oil had devastating consequences when prices crashed in the 1980s. The ensuing period was characterised by inflation, unemployment, food shortage, increasing national debt and a succession of military coups that culminated in the brutal and flagrantly corrupt Abacha regime (1993-1998). This deteriorating situation provided the material for Marching for Fausa, Two Horsemen and Resurrections which explore themes of oppression, violence, corruption, poverty and survival in worlds where the rule of law and logic have been abandoned.

This thematic enquiry is complemented by formal and stylistic experimentation. For Bandele, "absurd" encapsulates the chaotic ecosystems that have flourished in postcolonial Nigeria and the incredible modus operandi of some of its inhabitants: 'the theatre of the absurd should have actually started in Nigeria, because the whole country is one big stage where that sort of theatre has been played every day' (Bandele qtd in Ehling, 2001, 94). In Marching for Fausa, Two Horsemen and Resurrections Bandele presents his audience with strange, surreal and darkly comedic worlds that elicited comparisons with the absurdist dramas of Samuel Beckett and Harold Pinter in the press (see Hemming 1994). Bandele's works also sit within a Nigerian dramatic tradition. Wole Soyinka's impact is particularly evident in the way 
Bandele integrates Yoruba cosmology into his dramaturgy, his use of satire and the humanist world-view that undergirds the politics of his plays. Chinyere Nwahunanya identifies the influence of the European Theatre of the Absurd in dramas by J.P. Clark, Ola Rotimi and Wole Soyinka and argues that because of their canonical status the style has 'gradually taken roots [sic] in Nigerian theatre and dramaturgy' (1994, 171). ${ }^{5}$ The influence of the European Theatre of the Absurd on Bandele, therefore, was both direct (via Beckett) and already mediated (via Soyinka).

Despite the influence of the Theatre of the Absurd on Nigerian dramatic traditions and arguments for the existence of absurdist elements such as satire, hyperbole and fantasy in pre-colonial oral traditions (Balogun 1984, 44), modernist and postmodernist tendencies in African literature have been attacked as un-African by Afrocentric critics. The authors of Toward the Decolonization of African Literature critique African work and scholarly criticism in the 1980s that is 'slavishly imitative of 20th-century European modernism, with its ... ostentatious erudition, and dunghill piles of esoterica and obscure allusions, all totally cut off from the vital nourishment of our African traditions' (Chinweizu et al. 1983, 3-4). Notions of authentic African culture and opinions about the function of theatre have been deeply shaped by the anti-colonial struggle. Although an autochthonous African dramatic tradition is unachievable, movements such as Afrocentrism and Negritude championed the incorporation of folk performance forms, language and mythology as a means of "indigenising" dramaturgy and challenging Eurocentric epistemology. The Marxist ideology of the independence revolutionaries also imbued some writers with a commitment to bring about social change through their dramas. As Ania Loomba highlights:

many nationalists and anti-colonialists passionately, and often poetically appropriated the notion of a binary opposition between Europe and its others. Liberation, for them, hinged upon the discovery or rehabilitation of their cultural identity which European colonialism had disparaged and wrecked $(2015,178)$.

However, departures from these expectations in literature became increasingly evident as the 1980s progressed, particularly in work produced by writers referred to as the third generation. Unlike first- and second-generation writers, third-generation writers did not have a lived experience of colonialism. ${ }^{6}$ In his essay Warriors of a Failed Utopia? West African Writers Since the '70s second-generation Nigerian 
playwright Femi Osofisan (b. 1946) states that the writing of the third generation 'announces itself in a violent rupture with the goals of literature' (1996) of his generation. ${ }^{7}$ Osofisan refers to Bandele as 'among the most successful of our contemporary playwrights' (ibid.); however, he argues that this success, and that of the other writers he surveys, is contingent on their settlement in the West. ${ }^{8}$ Their 'living in exile' (ibid.), he states, has manifested an abstruse style that caters for Western postmodern tastes. 'One of the terms that have been used to describe the new movement' he notes, 'is African Absurdism' (ibid.). In considering if these writers are capable of nourishing their respective homelands (economically, culturally, politically, spiritually) from afar and in an alien style, Osofisan asks the question whether this new writing portends 'a new and refreshing beginning, or the failure of Utopia?' (ibid.). But, in positioning their work as antithetical to the Marxist aims of the second generation, Osofisan also implicitly questions the relationship of these writers to their "Africanness". Africanness here is perceived in literal and metaphoric terms: embodied by their proximity to the continent and embedded in their style and choice of subject matter. The implication is that the further a writer travels away from the continent - physically or imaginatively - the less "African" they become and by extension the less they are able to contribute to the utopian goals of nation building. On balance, Osofisan resolves his discussion by stating that 'rather than condemn these texts outrightly [sic], as being irrelevant to our needs [...] it is we the readers who must renew ourselves and our relationship with texts and the world' (ibid.).

In the discussions and analyses that follow, I shall be suggesting that the absurdism of Bandele's plays needs to be understood not as a single 'style', but as a fluid combination of different facets of dramaturgy and theatricality. Arguably, the concept of Afropolitanism provides a way in which to think about Bandele's plays that does not purvey essentialist notions of culture and identity conceptualized in terms of their opposition to the West.

\section{Afropolitanism}

The term Afropolitan entered popular discourse with the publication of an article by Taiye Selasi entitled 'Bye-Bye Babar' (2005). In it Selasi describes Afropolitanism as an emergent transnational and hybrid African immigrant identity: 'We are Afropolitans: not citizens, but Africans of the world' (ibid.). ${ }^{9}$ Selasi's 
conceptualisation of Afropolitanism is based on her experiences as a GhanaianNigerian who was born in the UK and grew up in the USA: 'Some of us are ethnic mixes $[\ldots]$ others merely cultural mutts' (ibid.). The historical context for her situation is the mass migration of skilled people from African countries who settled in the West (including Selasi's parents and Bandele) following political upheaval and economic turbulance in their homelands. In other words, Selasi's understanding of Afropolitanism developed, like the African Absurd, in reaction to, and as a critique of, the failures of African states in the post-independence period. It is therefore unsurprising that as a philosophy or a literary style, Afropolitanism and the African Absurd share a number of political and cultural perspectives that orbit around discourses of anti-essentialism and hybridity.

As an academic field of study Afropolitanism is in its early stages (Knudsen and Rahbek 2016, 13). Among those scholars who find the term productive, the notion of cultural hybridity is central to their conceptualisations, as Simon Gikandi describes:

To be Afropolitan is to be connected to knowable African communities, nations, and traditions; but it is also to live a life divided across cultures, languages, and states. It is to embrace and celebrate a state of cultural hybridity - to be of Africa and of other worlds at the same time $(2011,9)$.

Achille Mbembe (whose ideas have primarily informed my discussion of Bandele's plays) argues that three interconnected 'politico-intellectual paradigms' (anti-colonial nationalism, Marxism and pan-Africanism) have dominated African political and cultural discourses $(2007,26)$. Oriented around binary notions of culture, race and belonging that pit Africa against the West, these paradigms have nurtured what Mbembe terms a 'nativist reflex' (28). Nativism, according to Bill Ashcroft, Gareth Griffiths and Helen Tiffin is 'the desire to return to indigenous practices and cultural forms as they existed in pre-colonial society' $(2013,175)$. For Mbembe, nativism is a defensive position that resists an understanding of cultures and the world as interconnected, both historically and in the contemporary (2007). Afropolitanism, therefore, challenges this reductive and regressive way of thinking by articulating an anti-essentialist worldview that works with globalization and not against it.

Mbembe defines Afropolitan as 'a transnational culture' (2007, 29), produced as a result of the movement of people and products across borders. He, therefore, positions 
it as both a continental and diasporic experience. Although Afropolitanism describes the results of this movement (i.e. cultural hybridity) it also encompasses an understanding of the process of 'the interweaving of the here and there' (28). In other words, Afropolitanism is 'an effect of and a response to African experiences of globalization' (Knudsen and Rahbek 2016, 16). To this end, Afropolitanism has a political and philosophical dimension that promotes 'a way of being in the world' (Mbembe 2007, 28) or an understanding that one's 'identity can no longer be explained in purist, essentialist, and oppositional terms or by reference only to Africa' (Eze 2014, 240). As the name suggests, Afropolitanism is 'a form of cosmopolitanism with African roots' (Gehrmann 2016, 61). The articulation of an identity based on a sense of belonging anywhere and everywhere conveyed by the word cosmopolitan (from the Greek meaning 'citizen of the world') is kept in check by the prefix 'Afro-': a connection with Africa, literal or imagined, is intrinsic to its conceptualisation. An Afropolitan world-view is not, therefore, synonymous with philosophical universalism. Instead, as Chielozona Eze (2014) claims, Afropolitanism combines an awareness of African identities and cultures as rooted within specific contexts which are themselves positioned in a wider global space. Echoing Mbembe and drawing on cosmopolitanism philosophers such as Kwame Anthony Appiah, Eze argues that Afropolitanism articulates an ethical challenge that is located between universalism and particularism which is to understand oneself and one's own community in relation as opposed to in opposition to others (ibid.).

Afropolitanism's anti-essentialist stance and emphasis on hybridity and relation challenges political and cultural nativist discourse rooted in notions of authentic and indigenous African culture. Afropolitanism's rejection of nativism is particularly helpful for understanding Bandele's critique of contemporary Nigeria and is the focus of my discussion of Marching for Fausa, below. The way in which an anti-essentialist and anti-nationalistic political stance manifests a stylistic response to Afrocentric cultural discourses by emphasising hybridity over recuperation is discussed in relation to Resurrections in the Season of the Longest Drought. An Afropolitan approach troubles the automatic equation that "African" equals "non-Western" and, by extension, assumptions of what an authentic African play should read/look like. The way in which an identity based upon a sense of multiple belonging (geographic and cultural) manifests in writing that speaks across cultures is considered in Two Horsemen. 


\section{Marching for Fausa}

Although Marching for Fausa (1993) is set in a fictional military dictatorship named Songhai, Bandele intended the play to be a critique of Nigeria. ${ }^{10}$ Specific cultural references in the text (e.g. songs) and the use of certain props (e.g. Nigerian newspapers) when it was staged at the Royal Court in 1993 elicited direct comparisons with Nigeria in the press (Nightingale 1993; Taylor 1993). ${ }^{11}$

The play opens with the brutal police interrogation of a journalist named Telani. The narrative then goes back in time to explain how she arrived at this point. The catalyst for the play's plot is the illegal arranged marriage of a sixteen-year-old girl named Fausa to the Minister of Cultural Affairs. When a group of Fausa's school friends protest against the marriage they are arrested and detained. Fausa's attempt to expose this situation in the press is quashed by her corrupt editor. When an intervention by a delegation of Women's Union leaders fails to secure the children's release Telani leads the women in a public protest. However, the demonstration is violently suppressed and Telani is arrested. In prison Telani learns that the children are all probably dead and she is given the choice between turning informer or her own execution. As the play ends a radio broadcast announces there has been another coup in Songhai.

Described in the press as 'a series of cock-ups presided over by clowns' (Taylor 1993), Marching for Fausa is written in a satirical mode. The play derives its humour from ridiculing the actions of those in power. The police and government officials' incorrect use of language and bungled actions highlight their incompetency. There is a long history of socio-political satire in Nigerian performance traditions (see Adelugba et al. 2004; Ebewo 2001). In terms of drama, Wole Soyinka, in particular, is known for attacking corrupt politicians and the vulgarity of the elite (e.g. Kongi's Harvest and A Play of Giants). That Soyinka has influenced Bandele is evident by his incorporation of an extract from Soyinka's poem After the Deluge in the preface to Marching for Fausa. The quotation describes a tyrant who 'filled his heart-shaped swimming pool / With banknotes' (7). 
In Marching for Fausa Bandele strives to communicate a sense of this kind of excessive behaviour through larger-than-life characters and a heightened theatricality. Structurally, Bandele interrupts the linear narrative by splicing it with moments when Telani directly addresses the audience, radio broadcasts that provide wider contextual information and short sketch-like vignettes not directly related to the main storyline. One vignette, for example, highlights the transient nature of power in Songhai when an army officer is killed by a rival during his first address to the nation. The palaver is accompanied by lighting, sound and smoke effects as his body is 'unceremoniously dragged out of the studio' and 'a new army officer takes over the microphone' (25). Individually these moments draw attention to the close relationship between politics and performance. The play comprises a string of fairly short scenes which as a whole deliver a busy piece of theatre that communicates a sense of the regime's mismanagement. This structure also enables Bandele to incorporate a variety of styles through which to convey the absurdism of the wider context within which the main events occur.

In Marching for Fausa Bandele seeks to elicit an incredulous response from his audience by incorporating exaggerated, ridiculous and sometimes shocking representations that test the limits of believability. In these moments, the depiction of not just corrupt but irrational acts shifts the play into absurd territory. One scene, for example, depicts a group of policemen singing and cavorting around a pile of bail money on stage before they bring on one of the children in their custody who has been tortured. The stage directions state that the child's 'entire head area is covered in bandages' and 'where the mouth should have been there's a generous distension of flesh' (55). The merger of the comical with the violent veers the play away from a satirical portrayal of a corrupt system and towards a grotesque one in which corruption enables a system where barbaric acts can be committed without motivation or consequences. Marching for Fausa's representation of a nightmarish reality that defies rational explanation places the play within the tradition of African Absurdist texts identified by Kesteloot which, she observes, all end 'in madness, death or stupor' $(1996,6){ }^{12}$

The reviews of the production tended to focus on the play's treatment of the theme of tyranny. One reviewer praised the play's portrayal of 'the evils of dictatorship' but criticized its failure to provide historical context and to address 'Western 
responsibility for African autocracy’ (Billington 1993). The reviewer concluded that 'Bandele explores the symptoms of corruption and oppression without diagnosing their historical origins' (ibid.). However, this misses Bandele's point, which is to emphasise his characters' agency and accountability. Bandele deliberately resists contextualising his critique through colonialism and its legacy, placing blame squarely on the moral corruption and mismanagement of the government. This stance echoes his personal views of Nigeria: 'If any country in Africa deserves to be pitied, Nigeria is not such a country, simply because we mess things up ourselves' (qtd in Ehling 2001, 95). The onus, Bandele contends, in upon Nigerians to take responsibility for their actions: 'Until we Nigerians are able to sort this out, there is absolutely nothing anyone can do' (95).

Bandele does in fact provide a 'diagnosis' for the degenerate state of Songhai. The play braids issues of dictatorship, corruption and violence with patriarchy. It is not a play, as most of the reviews would suggest, just about dictatorship but about the relationship between dictatorship and nativism illustrated through the theme of women's oppression. At the start of the final scene the audience learn about how Telani's demonstration was quashed via a radio broadcast. The journalist reporting on the events is interrupted by the sound of gunshots and screams which, according to the stage directions, must last for nearly a minute (64). Following this, the broadcaster cheerily announces that the Sixth National Women's Day celebrations will continue as planned. One of the events of the day, the theme of which is obedience, will be 'an exhibition of the True African Woman' presented by 'the Army Officers' Wives' Association' (65). Bandele makes the ironic point that nationalistic rhetoric, once used for purposes of liberation by imagining a return to so-called African traditions has, in the context of post-independence dictatorships, been turned against the people to justify their oppression. In this moment the absurdity of this system is experienced through the sound effects. The length of time allocated to the shooting and screaming is intended to take the audience through a range of uncomfortable emotional responses in relation to the violence they are hearing and imagining, including horror, boredom and even humour. Through the representation of the government's violence against its citizens the play gives form to what Ashcroft, Griffiths and Tiffin identify as 'one of the principle dangers of nationalism' in postcolonial countries whereby a ruling elite 'frequently takes over the hegemonic control of the imperial power, thus replicating the conditions it rises up to combat' $(1995,151)$. Mbembe argues that in 
the post-independence era the ideology of anti-colonial nationalism organised around an 'us versus them' binary has been maintained. However, in the absence of an opponent in the West, violence is turned inwards $(2007,28)$.

In Marching for Fausa Bandele represents how this ideology has become redirected against those perceived as a threat to nationalistic principles of cohesion and solidarity structured around anti-Westernisation. The cultural implications of this political stance are discussed in the next play in relation to Bandele's stylistic approach. Afropolitanism's critique of nationalism enables ways of thinking about cultural interactions in more fluid terms as well as redirecting emphasis away from the authentic African / Westernized debate.

\section{Resurrections in the Season of the Longest Drought}

Set in Lagos in the mid-1980s, Resurrections in the Season of the Longest Drought (1994) presents Nigeria as a country in which corruption is endemic at all levels of society. The plot revolves around an affable Robin Hood-esque drug-dealer named Bikan Babarinsa (BB). When BB's drug smuggling operation is exposed, an attempt by his lawyer to bribe the judge to secure his freedom backfires: the judge keeps the money and sentences BB to death. In a surreal twist, BB is resurrected in the final scene and returns to Nigeria with magical powers and a mandate to improve the country.

The play is about wasted potential, with BB representing capable youths who have become corrupted by corruption. Like Marching for Fausa, Resurrections is written in a comedic vein but incorporates dark moments. The play achieves its satiric objectives through a mixture of tongue-in-cheek irreverence, pointed political barbs (e.g. BB tells a soldier at his execution that 'You should be pointing that gun at the people who placed it in your hands' (70)) and gallows humour.

As one of the characters in the play notes, in Nigeria 'anything goes' (49). Similarly, Bandele's heteroclitic style and sense of theatricality pushes the boundaries of realism in order to convey his vision of the incredible state of affairs that Nigeria's corrupt system has manifested. The play is written in three acts bookended by a prologue and epilogue. The first two acts are written in a magical realist style. In other words, the 
predominant realism of the scenes is occasionally interrupted by supernatural moments. In this case, two scenes in which characters are visited by the ghosts of dead relatives. In the third act, aptly entitled 'In the Hour of the Trickster God', the play veers towards farce when the judge mistakenly orders the wrong people to be murdered and peaks in the ludicrous when BB is executed by firing squad on a football pitch. The play ends in the bathetic when, in the epilogue, BB is sent back to the world of the living with 'a mandate to cleanse and [...] to kick ass' (79). As one reviewer noted, Resurrections is a 'stylistic mongrel which makes an interesting point - that there's a moment when corruption moves beyond satire into the realm of the fabulist' (Armitstead 1994).

Similarly to Marching for Fausa, in Resurrections Bandele incorporates moments of unexpected and exaggerated violence in order to communicate Nigeria's authoritarian regime as abhorrent and absurd. At one point, during a scene between $\mathrm{BB}$ and a police inspector we hear 'incessant' (54) lashings from off stage as his drug-dealing partner Yinka is beaten to death by the police. When BB questions why he can't hear Yinka's screams the inspector informs him complacently that his mouth has been stuffed with a loaf of bread. The policeman then performs a hunters' dance to 'the tortured rhythm of the flogging' (55) after which he translates its meaning as 'the prey ran out of luck. And God simply watches' (55). By disfiguring the relationship between crime and punishment to such an extent, this bizarre and extreme moment represents the culture of violence that was flourishing in Nigeria while simultaneously highlighting it as incomprehensible and grotesque. This was complemented by a symbolic stage design when the play was staged at the Cochrane Theatre in $1994 .{ }^{13}$ For example, the oppressive regime was dramatically portrayed during a scene in which the corrupt Judge sat at a large desk that rested upon a kneeling woman's head (see Kingston 1994). And throughout the production vultures on stilts patrolled the stage, simultaneously signifiers of the rotting society and, recalling the hunting dance, its overseers.

The theme of God's detachment echoes the explorations of the meaninglessness of life by the European post-war playwrights of the Theatre of the Absurd. However, in Resurrections God is not so much as dead as ignored. The behaviour of the elite suggests Nigeria is in the grip of a moral drought. The situation requires, as BB's resurrection suggests, an intervention of miraculous proportions to restore order. But, 
unlike Marching for Fausa, Resurrections is not without hope. BB's resurrection and the rain at the end of the play promises that a period of rejuvenation will follow. The moral ending is complemented by a shift to a more storytelling style. The dialogue of previous scenes gives way to long monologues and the text becomes more lyrical and the language more figurative. Resurrections sees Bandele experimenting further with performance traditions and dramatic styles in order to achieve a theatricality that conveys at a symbolic level the moral bankruptcy, social chaos and crisis in meaning produced by a system where corruption and violence have become the norm. As one of the beggars whom the recently resurrected BB has just cured of his blindness remarks in a moment that is symbolic, inter-textual and meta-theatrical: 'This can't be real. This is Kafka - on speed!' (79).

The magical and surreal world that Resurrections gives form to can be attributed to the influence of the surreal mind of Kafka and Christian mythology as well as the impish actions of the trickster god Eshu and Yoruba cosmology. Bandele's intercultural representations reflect his experiences of Nigeria as defined by deep cultural hybridization and religious syncretism. He grew up in a household and town in which he was exposed to Yoruba religious practices, Roman Catholicism, the Nigerian Cherubim and Seraphim Church and Islam (see Gibbs 2005, 96). Writing about Bandele's 1991 novel The Sympathetic Undertaker and Other Dreams Katrin Berndt observes that Bandele 'creates an image of contemporary Nigeria as perceived by young people who have neither experienced colonialism nor are stuck in 'precolonial traditions'. Linguistic, cultural, and religious hybridity, even syncretism, are what they perceive as normal' $(2007,82)$. While Berndt highlights Nigerian cosmopolitanism and the transcultural elements at play in Bandele's fiction, Osita Okagbue offers a different emphasis. In his survey of first and second-generation African drama (i.e. Bandele's plays are not included), Okagbue argues that works which incorporate traditional cultural practices become acts of 'cultural affirmation'; a way in which playwrights 'reclaim and recuperate the denigrated and emasculated cultural systems and practices of Africans and African-Caribbean peoples' $(2009,70)$. Although the result is an inevitable mélange, 'what unites all these efforts is their deliberateness - the dramatists seek to create theatre that is quintessentially African $[\ldots]$ in the way it appropriates and domesticates foreign elements, and in the way it updates indigenous forms' (149-150). 
It is true that in Resurrections Bandele draws more obviously on Nigerian (Yoruba) cultural traditions and cosmology than in his other plays. The Yoruba belief system that perceives the world in terms of the overlapping realms of the unborn, the living and the dead/ancestors can be identified by the way in which the spirits of the ancestors observe the living (represented in the play by the omnipresent vultures) and appear to them to offer council (hence the characters' unfazed reactions when visited by the spirits). In the final scene, the Iroko tree under which the resurrected BB performs miracles is also significant: according to Yoruba mythology Iroko trees are believed to house spirits which grant wishes. This metaphysical world-view and mythology provides Bandele with crucial elements of his dramaturgy. Okagbue demonstrates how the belief in the co-existence of three realms inhabited by the unborn, the living and the dead is incorporated into the content and form of African dramas (see 143-149). In this regard, the play can be positioned within a non-realistic Nigerian dramatic tradition. Bandele's use of a quotation from Soyinka's A Dance of the Forests in the preface to Resurrections further reiterates its position within a Nigerian dramatic tradition that employs folk forms and mythology for purposes of political critique.

However, subtle differences discernible in Bandele's approach indicate a slight shift away from the process of recuperation or appropriation and affirmation outlined in Okagbue's analysis of African playwrights. As Berndt notes of Bandele's fiction, in Resurrections (and his other plays) Bandele's stylistic influences reflect his experience of contemporary Nigeria as a syncretic cultural economy. One that was shaped but not defined by British colonialism, the struggle for independence and its achievement. Bandele's experimentation with style indicates his search for a way in which to critically convey the specific social and political turbulence of Nigeria as he experienced it growing up in the 1970s and 1980s. This has necessitated a departure from dramatic realism achieved by drawing on an array of cultural and literary influences in order to facilitate a satirical vision.

Bandele does not achieve this by deliberately crossing cultural boundaries but by embracing the fact that these boundaries have already been crossed. The European influences in his work are not freshly imported but part of Nigeria's hybridized cultural landscape and its local dramatic traditions. This supports the Afropolitan perspective that at a certain point imported cultures and their adaptation become, and 
must be viewed as, indigenous (Mbembe and Balakrishnan 2016, 34-35). Although Bandele draws on a range of cultural influences, by not drawing attention to Nigerian and Western cultural practices in a dialectical manner his choices are not supported by a belief system centred around the need to be recuperative. His plays, are not affirming of so-called African traditions in so far as they cannot simply be cleaved from European ones. Bandele's stylistic choices, therefore, should not be perceived through cultural politics but though his critique of corruption.

A defining feature of Bandele's Afropolitanism is his amalgamation of already amalgamated cultural and dramatic influences and elements which yields his particular composite version of absurdism as expressed dramaturgically and theatrically. In doing so, he proffers plays that are both indigenous and authentic while simultaneously undermining the notion of these words. This globalized cultural hybridity finds philosophical representation in Afropolitanism's notion of occupying a position in-between universalism and particularism and is discussed below in relation to Two Horsemen.

\section{Two Horsemen}

Through its exploration of the human condition and themes of religion, life after death, time and solitude Two Horsemen recalls Beckett's Waiting for Godot and Endgame, a resemblance noted by most of the reviewers of the production when it premiered at the Gate Theatre in $1994 .{ }^{14}$

Two Horsemen (1994) is set in a ramshackle room 'somewhere' (7). The play's protagonists are two street cleaners named Banza (Hausa for 'worthless') and Lagbaja (Yoruba for 'nobody in particular') who refer to each other using a number of names but never those given to them in the text. We are not provided any indication of when the action occurs. (A stopped clock symbolically forms part of the décor). Likewise, tangible details about their purpose and the world beyond the room are withheld. (A telephone in the room occasionally rings but is never answered). There are a number of references to a flood having occurred in the past and heavy rainfall outside. If, as in Resurrections, the rain signifies a new beginning, perhaps the purpose of these postapocalyptic everyman characters is to clean up the mess left behind by the planet's previous inhabitants? Banza and Lagbaja pass the time telling anecdotes from their 
past but, as the play progresses, the veracity of their stories is tested when they begin to contradict each other. Are they friends or father and son? Are they street cleaners as they say? Are they two of the four horsemen of the Apocalypse? (The other two, we are told, drowned in the flood). Perhaps they are the King's horsemen, expected, according to Yoruba tradition, to commit ritual suicide and follow their lord to the afterlife? In an oblique reference to Soyinka's Death and the King's Horseman, Lagbaja laments: 'In the old days, when the king died he was accompanied by his chief Horseman. You're lucky these days if you go with a carton of cigarettes. What has the world come to?' (55). The many derisive references to religion indicate that traditional spirituality has been replaced with tawdry materialism: Banza and Lagbaja, like their Beckettian counterparts, are alone and adrift in an incomprehensible world. The play's cyclic structure reiterates their entrapment. The text is broken up into sections of entertaining anecdotes. Once told, however, the scene reverts back to the mundaneness of their situation, announced by the repetition of the play's opening line: 'It rained yesterday. Did you know that? (9). Actions in the play provoke unexpected reactions. At one point Banza shoots Lagbaja in the head with an empty pistol and Lagbaja drops dead. After a momentary blackout Lagbaja is found sitting on a chair grinning as though nothing has happened. In its totality, the play makes no sense. Yet this is a case where the whole is less than the sum of its parts. If individual events in the play have any purpose, they are to underline the ridiculous world that the characters inhabit, where the logical relationship between cause and effect has become frayed.

Bandele's sampling of Beckett should not be perceived as evidence of his cultural colonisation. Neither should it be framed as a critique of the source text where the author deliberately Africanises or indigenises Euro-American canonical works in a challenge to the hegemony of Western art and epistemology. As opposed to an act of 'writing back' (Ashcroft et al. 1989) to Beckett, Bandele is writing with Beckett in an approach that stresses his belief in humanism over particularism. The play is a representation of the dissonant social effects caused by Nigeria's political situation and as experienced by ordinary people. By drawing on Beckett, Bandele is able to convey his perception of life in Nigeria which, based on his experience, is like living 'in a state of siege' where you have two choices: 'You either say it's crazy and retreat into a shell, or you just get into the thick of it and laugh' (qtd in Ehling 2001, 94). Unlike Waiting for Godot, Two Horsemen is not an existentialist study of the human 
condition but an ode to irreverence, stoicism and the clowning Bandele finds in abundance on the streets of Nigeria. It is not universal or transcendent but materially connected. For Bandele the absurd is a positive way to approach reality: 'a way of looking at life, at existence, that is itself full of pathos - and coming out grinning' (ibid.). The play ends on a note of survival, which highlights that it is not a story about what an intolerable world had done to Banza and Lagbaja but what they do in this intolerable world.

BANZA: We'll always survive.

LAGBAJA: Yes.

BANZA: There'll be bad times and not-so-good times. Good times and so-so times. But we'll always survive. (62).

This emphasis on agency corroborates Fidelis Odun Balogun's point that the major difference between the African and European Absurd is philosophical: 'The African absurdist writer does not believe that life in itself is absurd or meaningless. As a matter of fact, life to him is very meaningful; what can be absurd and meaningless are individuals and situations' $(1984,46)$. That this difference in approach was noted by the audience is evident from the reviews of the production. For example, one critic highlights that although Two Horsemen might appear to border on the 'derivative' it differentiates itself from Waiting for Godot through its use of humour which renders a tone 'more mischievous than despairing' (Nightingale 1994). Bandele's reliance on the audience's shared cultural knowledge of Beckett and the universality of his themes arguably allows them to accept the Nigerian context of the play and any unfamiliar representations more readily. ${ }^{15}$ Arguably, the play gives form to Appiah's understanding of cosmopolitanism as an ethical challenge to recognise similarities and forge connections between foreign cultures and people while simultaneously respecting their differences (2006).

\section{Conclusion: Afropolitanism and Theatre Practice}

Afropolitanism is a cultural and philosophical concept that articulates a position between the local and the global, universalism and particularism. By conveying a specific association with Africa the term sidesteps a generalized cosmopolitanism and draws attention to how experiences are structured and cultures are (re)shaped within national, regional and even continental borders. At the same time the term embraces 
cosmopolitanism's tenet of a global citizenry and humanist ideals. Bandele recalls his first visit to the theatre 'in a manner of speaking' occurring as a young boy watching an adaptation of John Osborne's 1956 play Look Back in Anger on television in Nigeria. This event reminds us that in an increasingly mediatised and globalized world transnational cultural interactions operate within and through physically rooted communities. For the impressionable Bandele the themes resonated with his personal experiences and context:

I had encountered such inchoate and atavistic rage before - after all, I was growing up in a society that was still reeling from a 30-month civil war in which more than a million people had died [...] And so although I had yet to set foot outside Kafanchan, although I knew nothing about post-war British society, or the Angry Young Men, or anything about Osborne when I met Jimmy Porter on the screen of that hire-purchase television set, I knew there was no need for introductions: I had known Jimmy all my life (2003).

This moment of cross-cultural identification interpreted through his localised experience would come to define Bandele's playwriting. However, it would not be the 'kitchen-sink' realism of the Angry Young Men who Bandele would turn to for inspiration on how to represent his experience of Nigeria but absurdism. Bandele's use of absurdism in Marching for Fausa, Two Horsemen and Resurrections enabled his searing state-of-the-nation non-didactic critiques. But his complex stylistic choices also implicitly critique Nigerian (and African) artistic discourses. His representations challenge nativist and nationalist approaches and undermine assumptions of traditional and authentic African culture. In doing so, Bandele's plays draw attention to Africa and Africanness as constructed categories. Therefore, the solution Bandele proffers to the meaningless violence, anger and oppression exposed in his thematic explorations is located within the form not the content of his plays: to cross borders, real and imaginary; to embrace different cultures and beliefs; to live in the world as it is not what it was; and, despite Osofisan's misgivings, the utopian pursuit of human truth. This cosmopolitan universalism is nevertheless tempered by relativism. The plays discussed in this chapter are inscribed by Bandele's specific experiences of Nigeria. At the same time their multi-cultural influences demand they are read - as they were written and seen - 'as being part of the world rather than being apart' (Mbembe and Balakrishnan 2016, 29). 
Bandele's emergence on the theatre scene during the 1990s marked the beginning of a new wave of African (particularly Nigerian) theatre activity in the UK (see Pearce 2017, 155-177). This was enabled by an increase in migration to the UK from African countries, particularly Nigeria. Between the censuses of 1991 and 2001 the number of Nigerian-born people living in the UK (mainly in London and the South East) increased by $87 \%$ (BBC News 2005). The repercussions of this mass migration on the theatre landscape would become particularly visible in the new millennium with the emergence of a number of high-profile Nigerian British playwrights who were born or grew up in Britain, including Bola Agbaje, Lizzy Dijeh, Arinze Kene and Janice Okoh.

Furthermore, Bandele's critical exploration of Nigerian issues and progressive political views expressed through an experimental and comedic style anticipated similar works by African British playwrights who would emerge in the new millennium. Since Bandele's debut, first-generation African British immigrants or those with a lived experience of an African country continue to make theatre which complicates representations of Africa on the British stage. Three actors who met as cast members of Marching for Fausa - Patrice Naiambana (Sierra Leone), Jude Akuwudike (Nigeria) and Femi Elufowoju Jr. (British-born and raised in Nigeria) attempted to create a specifically African British theatre group that would challenge stereotypes of Africa and African immigrant (Ogungbe n.d.). Fraudsters Inc. was a short-lived company that only produced one piece entitled It's Good to Talk at the Theatre Royal Stratford East in London. However, in 1997 Femi Elufowoju Jr. established Tiata Fahodzi which has since become Britain's longest-running African British theatre company. Since its inception, Tiata Fahodzi has nurtured a number of playwrights who, like Bandele, could be described as Afropolitan. Among them, Oladipo Agboluaje (British-born but raised in Nigeria), whose plays The Estate and Iyà-Ilé were produced by Tiata Fahodzi in 2006 and 2009 respectively, and Denton Chikura (Zimbabwe), whose The Epic Adventure of Nhamo the Manyika Warrior and his Sexy Wife Chipo was produced in 2013. Like Bandele's plays, these writers' lived experience of cosmopolitan Africa and familiarity with local performance and literary traditions yields complex representations of contemporary African and African diasporic experiences. Perceiving Afropolitanism as an exclusively diasporic experience, therefore, risks conflating cosmopolitan culture with the West when in fact Bandele's and later arrivals' multi- and inter-cultural experiences occurred in 
their African homelands. In other words, Bandele's plays are not Afropolitan because

of his relocation to Britain: he brought an Afropolitan sensibility to the British stage.

\begin{abstract}
${ }^{1}$ Rain (unpublished) was produced in 1990 in Scarborough for the National Student Drama Festival.
${ }^{2}$ In addition to those discussed in this chapter, Bandele's has written the following stage plays: Death Catches the Hunter (1995, the Battersea Arts Centre); Me and the Boys (1995, Finborough); Things Fall Apart (1997, West Yorkshire Playhouse and touring), based on the novel by Chinua Achebe; Thieves Like Us (1998, Southwark Playhouse); Oroonoko (1999, The Other Place, Stratford-uponAvon), based on the novella by Aphra Behn; Happy Birthday, Mister Deka D (1999, Traverse Theatre, Edinburgh); Yerma (2001, Edinburgh Fringe Festival), based on the play by Federico García Lorca; and Brixton Stories (2001, Tricycle Theatre) adapted from his own novel, The Street.

${ }^{3}$ Bandele's novels include The Man Who Came in from the back of Beyond (1991), The Sympathetic Undertaker and Other Dreams (1991) and The Street (1999). In their mapping of Nigerian third generation writing Adesanmi and Dunton note these novels as the first fictional works from thirdgeneration Nigeria authors 'to break into the transnational academic canon' $(2005,10)$.

${ }^{4}$ Most academic attention has been placed on Bandele's adaptation of Oroonoko: see Widmayer (2003), Wallace (2004) and Munns (2014).

${ }^{5}$ For discussions which highlight the Theatre of the Absurd in Soyinka's plays, specifically The Road,
\end{abstract} see, for example, Acholonu (1984) and Nwahunanya (1994).

${ }^{6}$ In terms of literary classification, the first generation refers to African writers who were born during colonialism and who came to maturity around the time of independence in 1960 (e.g. Wole Soyinka b. 1934). The second generation were also born during colonialism but came to maturity in the immediate independence period (e.g. Femi Osofisan b. 1946). Having this experience of colonialism in common meant that, in the words of Adesanmi and Dunton, 'their textualities were therefore massively over determined by that experience' (Adesanmi and Dunton 2005, 14).

${ }^{7}$ The essay was originally delivered as a speech at The Second Annual African Studies Lecture at the University of Leeds on the 24th April 1996.

${ }^{8}$ In their overview of the three generations of Nigeria's writers Adesanmi and Dunton note that 'there is only one third generation dramatist who has achieved anything like the prominence of second generation playwrights such as Femi Osofisan [...] namely, Biyi Bandele' $(2005,12)$.

${ }^{9}$ Since the publication of Selasi's article a number of debates about the term's merits as a marker of identity and its political potential have emerged, particularly in the blogosphere. Critics argue that it articulates an elitist identity and is driven by neo-liberal consumerist values. See, for example, Emma Dabiri's Diaspora Diva blog www.emmadabiri.com and Minna Salami's Ms Afropolitan blog http://www.msafropolitan.com

${ }^{10}$ The name Songhai is a reference to the Songhai Empire of West Africa that existed during the $15^{\text {th }}$ and $16^{\text {th }}$ centuries.

${ }^{11}$ Marching for Fausa was directed by Annie Castledine. The author did not see the production, of which there is no available recording. Photographs and reviews of the production can be accessed at the English Stage Company/Royal Court Theatre Archive held at the V\&A Theatre and Performance Collections in London. Ref: GB 71 THM/273/6/1/313.

12 Anglophone African playwrights whose works have been linked to the Theatre of the Absurd include, among others, Kenyan Francis Imbuga, Nigerian Wole Soyinka, South African Zakes Mda, Ugandan Robert Serumaga and Zimbabwean Dambudzo Marechera.

${ }^{13}$ Resurrections was produced by Talawa Theatre Company, the UK's longest running black-led theatre company. It was directed by then Artistic Director Yvonne Brewster and designed by Ellen Cairns. A black and white video recording of the production can be accessed at the Talawa Theatre Company archive held at the V\&A Theatre and Performance Collections in London. Ref: GB 71 $\mathrm{TTC} / 7 / 2 / 9$.

${ }^{14}$ Two Horsemen was developed from Rain. It was first performed at the Gate in 1994 as part of the London New Play Festival, where it won the London New Play Festival Award. It was directed by Roxana Silbert. Later that year, following the première of Resurrections, Two Horsemen transferred to London's Bush Theatre.

15 This is also evident in Bandele's adaptation of Lorca's Yerma in which he maintains the source text's ideological and architectural parameters. Bandele transposed the play from early twentieth century rural Spain to contemporary rural northern Nigeria because he felt that the Nigerian setting would allow the audience to accept the premise of the original more readily, better serving the text's emotional affect (qtd in Brown 2001). 


\section{Works Cited}

Acholonu, C. (1984), 'A Touch of the Absurd: Soyinka and Beckett', African Literature Today, (14), 12-18.

Adelugba, D., Obafemi, O., and Adeyemi, S. (2004), 'Nigeria', in Banham, M. ed., $A$ History of Theatre in Africa, Cambridge, Cambridge University Press, 138158.

Adesanmi, P., and Dunton, C. (2005), 'Nigeria's Third Generation Writing: Historiography and Preliminary Theoretical Considerations', English in Africa, 32(1), 7-19.

Appiah, A. (2006), Cosmopolitanism: Ethics in a World of Strangers, London, Allen Lane.

Armitstead, C. (1994), 'Resurrections', The Guardian, 10 October, T7.

Ashcroft, B., Griffiths, G., and Tiffin, H. (1989), The Empire Writes Back: Theory and Practice in Post-Colonial Literatures, London, Routledge.

---. (1995), 'Introduction to Part V: Nationalism', in Ashcroft, B., Griffiths, G., and Tiffin, H. eds., The Post-Colonial Studies Reader, London, Routledge, 151152.

---. (2013), Post-colonial Studies: The Key Concepts, London, Routledge.

Balogun, F. O. (1984), 'Characteristics of Absurdist African Literature: Taban lo Liyong's Fixions - A Study in the Absurd', African Studies Review, 27(1), pp. 41-55.

Bandele, B. (1993), Marching for Fausa, Charlbury, Amber Lane.

---. (1994a), Resurrections in the Season of the Longest Drought, Charlbury, Amber Lane.

---. (1994b), Two Horsemen, Charlbury, Amber Lane.

---. (2003), 'Read Between the Signs', The Guardian, 26 April, 18. [Accessed 16 August]. Available from: https://www.theguardian.com/stage/2003/apr/26/theatre.artsfeatures1

BBC News. (2005), 'Born Abroad: Nigeria', [online]. [Accessed 23 August 2017]. Available from: http://news.bbc.co.uk/1/shared/spl/hi/uk/05/born_abroad/countries/html/nigeri a.stm

Berndt, K. (2007), 'West Africa', in Eckstein, L. ed., English Literatures Across the Globe: A Companion, Paderborn, Wilhelm Fink, 61-85.

Billington, M. (1993), 'Marching for Fausa', The Guardian, 15 January, 8. 
Brown, M. (2001), 'Spain May Have Moved On, But The Flamenco Spirit of the Past is Still Alive in Rural Nigeria, Scotland on Sunday, 19 August, 15.

Cavendish, D. (1999), ‘Oroonoko lives again', The Independent, 24 March, 11.

Chinweizu, Jemie, O., and Madubuike, I. (1983), Towards the Decolonization of African Literature, Washington, D.C., Howard University Press.

Ebewo, P. (2001), 'Satire and the Performing Arts: The African Heritage', in Losambe, L., and Sarinjeive, D. eds., Pre-Colonial and Post-Colonial Drama and Theatre in Africa, Claremont, New Africa Books, 48-58.

Ehling, H. (2001), 'Coming out Grinning', in Ehling, H., and Holste-von Mutius, C.P. eds., No Condition is Permanent: Nigerian Writing and the Struggle for Democracy, Amsterdam, Rodopi, 91-97.

Esslin, M. (2014), The Theatre of the Absurd, London, Bloomsbury.

Eze, C. (2014), 'Rethinking African Culture and Identity: The Afropolitan model', Journal of African Cultural Studies, 26(2), 234-247.

Gehrmann, S. (2016), 'Cosmopolitanism with African Roots. Afropolitanism's Ambivalent Mobilities', Journal of African Cultural Studies, 28(1), 61-72.

Gibbs, J. (2005), 'Bandele, Biyi (1967-) Nigerian Poet, Playwright, Short-Story Writer, Novelist', in Benson, E., and Conolly, L. W. eds., Encyclopedia of Post-Colonial Literatures in English, London, Routledge, 96-97.

Gikandi, S. (2011), 'Foreword: On Afropolitanism', in Wawrzinek, J., and Makokha, J. K. S. eds., Negotiating Afropolitanism: Essays on Borders and Spaces in Contemporary African Literature and Folklore, Amsterdam, Rodopi, 9-11.

Hemming, S. (1994), 'The Unbelievable Truth', The Independent, 28 September, 21.

Kesteloot, L. (1996), 'Turning Point in the Francophone/African Novel: The Eighties to the Nineties', in Jones, E. D., and Jones, M. eds., New Trends and Generations in African Literature. 4-13.

Kingston, J. (1994), 'Coruscating Study in Corruption', The Times, 5 October.

Knudsen, E. R., and Rahbek, U. (2016), In Search of the Afropolitan: Encounters, Conversations, and Contemporary Diasporic African Literature, London, Rowman \& Littlefield International.

Loomba, A. (2015), Colonialism/Postcolonialism, 3rd ed, London, Routledge.

Mbembe, A. (2007), 'Afropolitanism', (Chauvet, L., Trans.), in Keller, C. ed., Africa Remix: Contemporary Art of a Continent, Johannesburg, Jacana, 26-30.

Mbembe, A., and Balakrishnan, S. (2016), 'Pan-African Legacies, Afropolitan Futures: A Conversation with Achille Mbembe', Transition, 120(1), 28-37. 
Munns, J. (2014), 'Two Oroonokos: Behn's and Bandele's', in Richards, C., and O'Donnell, M. A. eds., Approaches to Teaching Behn's Oroonoko, New York, Modern Language Association of America, 162-166.

Nightingale, B. (1993), 'Packaging a Cause to Little Effect', The Times, 14 January.

---. (1994), 'Beckett Rides Again in Africa', The Times, 3 November.

Nwahunanya, C. (1994), 'Nigerian Drama and the Theatre of the Absurd', Neohelicon, 21(2), 169-189.

Ogungbe, J. (n.d), 'Fraudsters Inc', Black Perspective, [Accessed 10 Aug 2016]. Available from: http://blackperspective.co.uk/display_content.php?show=stories\&id=14

Okagbue, O. (2009), Culture and Identity in African and Caribbean Theatre, London, Adonis \& Abbey.

Osofisan, F. (1996), 'Warriors of a Failed Utopia? West African Writers Since the '70s', Leeds African Studies Bulletin, [Accessed 10 Aug 2016], Available from: http://lucas.leeds.ac.uk/article/warriors-of-a-failed-utopia-femi-osofisan/

Pearce, M. (2017), Black British Drama: A Transnational Story, London, Routledge.

Selasi, T. (2005), 'Bye-Bye Babar', The LIP, 3 March, [Accessed 9 March 2016], Available from: http://thelip.robertsharp.co.uk/?p=76

Swarns, R. (1999), 'The Red Clay and Sorrow of Nigeria', The New York Times, 14 February, [Accessed 16 August 2016], Available from: http://www.nytimes.com/1999/02/14/theater/theater-the-red-clay-and-sorrowof-nigeria.html

Taylor, P. (1993), 'Cross-Currents of Darkness', The Independent, 16 January, [Accessed 20 February 2011], Available from: http://www.independent.co.uk/arts-entertainment/theatre-cross-currents-ofdarkness-paul-taylor-on-marching-for-fausa-at-the-royal-court-and-heart-at1478882.html 